\title{
METHODS TO IMPROVE THE EFFICIENCY OF THE BUSINESS PROCESS OF REPAIRING POWER-GENERATING EQUIPMENT
}

\author{
VASILYEVICH Pakhomov Sergey ${ }^{1}$, ALEKSANDROVICH Siutin Denis ${ }^{2}$ \\ ${ }^{I}$ Peoples' Friendship University of Russia (RUDN University) (RUSSIAN) \\ ${ }^{2}$ Research Institute of Economics and Management Organization in the Gas Industry "- LLC "NIIgazekonomika"Moscow, \\ (RUSSIAN) \\ E-mail:Avalanshe_83@mail.ru,danasi80@mail.ru
}

\begin{abstract}
The paper considers the methods to improve the efficiency of the business process of repairing powergenerating equipment, as one of the main directions for increasing the efficiency and safety of the company activity as a whole.

The efficiency of power generating companies is currently determined by the quality of the fieldoriented and supporting business processes arrangement. Companies in the power-generating sector have strict environmental and energy security requirements. Accidents at production and transport facilities can cause irreparable environmental deprivations. Also, the failure of the mains sections can completely stymie the work of large settlements, and endanger the life and health of people in the cold season.

The performance of the equipment can be impaired as a result of natural causes (corrosive wear, metal fatigue, and other deformations) and due to violation of the operating mode. The good condition of the processing equipment is ensured by the maintenance and repair works performed in time. Company's experience has proven that, for the safe operation of processing equipment, it is necessary to annually appropriate funds in the amount of at least $2 \%$ of the initial cost of the equipment. The main focus should be on planning and arranging the processes involved.

Safe operation can also mean availability to purchase equipment necessary for production tasks. Many large power generating companies are trying to act under the principle of technological self-sufficiency. It implies the presence of technological developments in intellectual property, as well as production facilities. The implementation of this principle is possible both through the development of own scientific resources, and through the absorption of industrial enterprises. All this gives a competitive advantage to power generating companies, as well as expands the range of services provided.
\end{abstract}

Key words: business process, efficiency improvement, power-generating equipment, repair service, labor coefficient.

JEL:L26

DOI: $10.5937 /$ intrev2102164V

UDC: 005.336.1:005.4

005.934.4:621.313.52

COBISS.SR-ID 43529993 


\section{INTRODUCTION}

The essence of the repair is to bring the operating modes of the processing equipment to the specified operating parameters, by performing restoration work, as well as replacing its individual parts and assemblies. Ensuring the safe operation of processing equipment is the main task of operating organizations. Considering the importance of equipment in performing production tasks, repair is one of the key business processes of industry management, which ensures its safe and efficient operation.

The type of repair service organization in the modern understanding should correspond to the production objectives of the enterprise, taking into account the understanding of the criticality of equipment failure. In actual experience, the following types of maintenance and repair are used [1]:

- system of scheduled preventive maintenance;

- proactive maintenance;

- reactive maintenance;

- maintenance according to technical condition.

The system of scheduled preventive maintenance includes scheduled preventive measures to ensure the safe operation of processing units with high performance indicators [2][3].

Proactive maintenance is intended to increase the reliability of processing plants by improving design features based on the results of monitoring performance indicators and statistical data on equipment malfunctions [2][4].

Reactive maintenance system is characterized by the shutdown of processing units for repair after the detection of malfunctions, as a result of which operation is impossible. [2][5].

Repair according to the technical condition is performed on the basis of information obtained from the maintenance personnel based on the results of monitoring production indicators and observing the process of operation of the processing unit in [2][6].

Table 1: "Advantages and disadvantages of various types of maintenance service"

\begin{tabular}{|l|l|l|}
\hline Types of repair service & \multicolumn{1}{|c|}{ Disadvantages } & \multicolumn{1}{|c|}{ Advantages } \\
\hline $\begin{array}{l}\text { System of scheduled } \\
\text { preventive maintenance }\end{array}$ & $\begin{array}{l}\text { - an increase in the cost of repairing/replacing } \\
\text { properly functioning parts and equipment assemblies. }\end{array}$ & $\begin{array}{l}\text { - minimization of failure of } \\
\text { processing units of } \\
\text { equipment. }\end{array}$ \\
\hline Proactive maintenance & $\begin{array}{l}\text { - an increase in the cost of expanding the personnel of } \\
\text { engineering and design departments in the } \\
\text { organization }\end{array}$ & $\begin{array}{l}\text { - increasing the reliability of } \\
\text { processing units; } \\
\text { - reducing the cost of } \\
\text { emergency repairs. }\end{array}$ \\
\hline Reactive maintenance & $\begin{array}{l}\text { - potential non-maintainability of failed equipment; } \\
\text { - an increase in the risk of penalties due to non- } \\
\text { fulfillment of obligations under contract for the supply } \\
\text { of power resources; } \\
\text { - the probability of simultaneous fail of several } \\
\text { processing units }\end{array}$ & $\begin{array}{l}\text { - savings on planned repairs } \\
\text { and restoration works. }\end{array}$ \\
\hline $\begin{array}{l}\text { Maintenance according } \\
\text { to technical condition }\end{array}$ & $\begin{array}{l}\text { - the probability of simultaneous fail of several } \\
\text { processing units. }\end{array}$ & $\begin{array}{l}\text { - reduction of scheduled } \\
\text { preventive maintenance } \\
\text { work. }\end{array}$ \\
\hline
\end{tabular}

Source: compiled by the authors of the study.

For enterprises in the power generating sector, it is most reasonably to use proactive maintenance, which is aimed at minimizing the probability of equipment function loss.

Enterprises in the power generating sector of the economy have a special status, as a result of which they have the following peculiarities in arranging repair services:

1. The equipment is repaired on a scheduled basis and includes current and long-term planning. Long-term planning is the development of plans and programs for the next three years, while current planning is created for the next year. Scheduled repairs are performed according to the results of the operating hours of processing equipment in accordance with the established requirements in machine hours and in calendar days. 
2. An alternating sequence of scheduled repairs of various types (current, medium, overhaul) create a repetitive repair cycle.

3. Each scheduled repair of processing equipment is performed in the scope that fully restores its wear for the previous operating period. The performed repairs must ensure the efficient and safe operation of the processing equipment until the next scheduled repair, the conditions for the occurrence of which are indicated in the regulatory documents or in the equipment technical data sheet.

4. In the period between scheduled repairs, diagnostic examinations and technical inspections are performed on each equipment, as a result of which defects are identified, minor of which are eliminated, equipment is balanced, and based on the results of the identified defects, a list of parts and assemblies to be purchased prepared. At the onset of scheduled repairs these parts and assemblies are necessary for replacement. This list of measures is necessary in order to assess the technical condition of the equipment when planning repair works.

The interaction of all participants in the business process of repairing processing equipment can be considered as the economic relations of the participants in this business process, whose interests are mediated by the corresponding document workflow and includes the following stages:

- planning of repair works;

- arrangement of repair work;

- supporting of repair work.

At the stage of planning repair works, design solutions are developed, cost limits are determined based on the rates of consumption of materials and equipment. At the stage of arranging the repair work, procurement of materials and equipment and services takes place, a delivery schedule is approved, work is arranged to shutdown power generating equipment for repair and quality control procedures of the services provided. At the supporting stage, analytical work is performed to determine the effectiveness of the repair service arrangement.

It is possible to reduce equipment downtime caused by probable breakdowns of parts and assemblies due to effective planning of repair work performance, while a significant part of the preparatory work is performed during time between overhauls. But it is also necessary to take into account that as a result of physical wear and tear there comes a moment for each operating processing equipment when its operation becomes economically inadvisable; in this case it is subject to replacement [2].

In case of absence of its own repair departments at the enterprise, the repair of processing equipment can be performed by third-party specialized organizations.

Table 2 Advantages and disadvantages of outsourcing implementation in the repair activities of the enterprise.

\begin{tabular}{|l|l|}
\hline \multicolumn{1}{|c|}{ Advantages } & \multicolumn{1}{c|}{ Disadvantages } \\
\hline $\begin{array}{l}\text { Compliance with the staffing position limit (there is no } \\
\text { need to expand the staff) }\end{array}$ & Loss of control over own resources (under repair) \\
\cline { 1 - 1 } $\begin{array}{l}\text { Reduction of time spent on management, search and } \\
\text { involvement of specialists to perform repairs }\end{array}$ & $\begin{array}{l}\text { The risk of ovepricing and non-transparency of the cost } \\
\text { (cost formation) of works. }\end{array}$ \\
\cline { 1 - 2 } $\begin{array}{l}\text { The ability to redistribute assets to a strategically more } \\
\text { important area of activity }\end{array}$ & \\
\cline { 1 - 2 } Maintenance service guarantee & \\
\hline
\end{tabular}

Source: compiled by the authors of the study.

\section{METHODS FOR THE DEVELOPMENT OF THE BUSINESS PROCESS OF REPAIRING POWER GENERATING EQUIPMENT.}

In the course of the implementation of repair services at the enterprises of the power generating sector, the selection of the repair object is performed, the necessary list and scope of the work performed and their cost are determined, contracting organizations are selected, and so on. In order to improve the management of the repair business process, it is possible to use the following methods:

- the method of ranking the objects of repair;

- the method of setting achievable indicators;

- the method of regulatory support of the repair work cost. 


\section{METHOD FOR RANKING OBJECTS OF REPAIR}

This method can be used when planning repair works in conditions of insufficient funding. The essence of this method consists in the selection of repair objects of paramount importance, the failure of which can significantly affect the performance of the unified gas supply system.

The application of the method of assessments and ranking at the enterprises of the power generating sector will make it possible to assess the level of influence of a particular equipment, unit on the functioning of the technological process at the enterprise $[7,8]$.

Existing approaches for the development of assessment systems in economics should be based on integral parameters.

The following stages of the process for calculating the integral parameter and ranking of repair objects can be distinguished [9]:

-development of a system of parameters of the investigated repair objects according to the type of activity;

-calculation of integral indices;

-ranking of repair objects according to the obtained integral parameters.

In order to develop an assessment system for the order of priority, it is necessary to identify key parameters that can be used for unbiased determination of the equipment to be repaired.

There are various methods for determining the integral parameter: the method according to the sum of parameters (linear model), the method according to the sum of the average weighted group parameters, the method according to the product of the average weighted geometric group parameters, the distance method.

Parameters sum method (method according to the sum of parameters (linear model)

The essence of the method consists in compiling a list of key factors and each of them is given an expert assessment on a scale from 1 to 10 . In order to obtain a complex parameter, the assessments are summed up (Formula 1).

Formula 1

$\mathrm{x}_{\mathrm{i}}$ - value of the i parameter.

$$
X_{\text {int }}=\sum x_{i}
$$

Since not all the parameters have a significant role for the object under study, the fairness of the parameters sum method is extremely small.

The method according to the sum of the average weighted group parameters

The calculation of the integral parameter according to this method allows taking into account the parameter of significance, in this regard, the activity efficiency of the object under study is more accurately reflected (Formula 2).

Formula 2

$$
X_{\text {int }}=\sum w_{i} \cdot x_{i}
$$

$\mathrm{x}_{\mathrm{i}}-$ value of the i parameter by the total number $\mathrm{N}$;

$\mathrm{w}_{\mathrm{i}}$ - parameter of significance (weight) of the i parameter.

The method according to the product of the average weighted geometric group parameters.

This method is the most time consuming, and the assessment of weight parameters is performed by calculation, therefore it is the most unbaised and accurate (Formula 3).

Formula 3

$$
X_{\text {int }}=\prod_{i=1}^{N} x_{i}^{w_{i}}
$$

$\mathrm{x}_{\mathrm{i}}-$ value of the i parameter by the total number $\mathrm{N}$;

$\mathrm{w}_{\mathrm{i}}$ - parameter of significance (weight) of the i parameter;

$\Pi$-product of arguments $i=1,2,3, \ldots, N$. 
Enterprises in the power generating sector of the economy include various functional and technological business processes, while the key parameters can be considered as follows:

1) the significance of the object for the enterprise operation;

2) the actual technical condition of the object;

3) the effectiveness of the repair for the enterprise.

Considering these parameters in aggregate, it is possible to prioritize the withdrawal of equipment for repair.

Determination of the systemic importance of the equipment will allow obtaining an accurate and unbiased assessment of its impact on the operation of the entire technological process at the enterprise.

The ranking system should be developed separately for each functional business process. For the gas industry, there will be the following steps:

- natural gas production;

- natural gas processing;

- transportation of natural gas;

- underground storage of natural gas.

The ranking of objects to be repaired is the process of sequencing the objects under study by creating a classification list based on ratings and is a kind of risk-oriented planning method. Since the probability of process equipment failures is a random variable, this uncertainty must be taken into account in the process of planning repair works.

For each functional business process, its own criteria for the significance of equipment are determined, and in the process of comparing the obtained values according to the established criteria, the type of processing equipment is determined, the shutdown for repair of which is of paramount importance.

\section{METHOD OF SETTING ACHIEVABLE INDICATORS}

The practical implementation of the method for setting achievable indicators in the field of arranging repair services allows us to identify hotspots at various stages of arranging repair production, through the use of an evaluation system for each stage of the business process.

Indicators are developed for each stage of the repair business process separately. For example, for the planning stage, an important criterion for assessing its effectiveness may be the presence of ranking systems when selecting a repair object, as well as the price justification of the cost of repair work.

The use of the method for setting achievable indicators also allows to obtain a comprehensive assessment of the work arrangement for each repair work performed at the enterprise.

Such achievable indicators, for example, can be:

- Method of regulatory support of the repair work cost

- When planning repair work, in order to determine the initial (maximum) cost of repair services, reference books, price lists, as well as other regulating documents governing the procedure, scope of work, structure and labor consumption standards (in man hours) are used.

Modern operating conditions of power generating equipment are characterized by the uniqueness of each object. The transition from standard solutions to individual projects had a negative impact on the regulatory support of repair services. The most important criterion affecting the final cost of repairs is labor coefficient. Labor coefficient characterizes the cost of working time to perform a processing operation (work) [10].

It should be noted that one of the main problems in the development and updating of regulatory documents for the standardization of repair work is the determination of a reasonable level of labor coefficient. The formation of the labor coefficient value should be performed taking into account the following criteria [10][11][12][13]:

- optimal processing procedure (scope of work) for maintenance and repair;

- optimal qualification stuff of repair personnel;

- optimal time for performing a specific work (set of works); 
- corrective actions to timely update regulatory data;

- supervising function for compliance with the application of regulatory documents in determining the cost of repairs.

The most reliable methods for determining labor coefficient are the analytical and research method and the analytical and calculation method.

The analytical and research method for determining the labor coefficient is based on time measurements, pictures of the working day and is performed in places where repair works are performed by means of observations. Time costs for the production of works (operations) are accounted for as actual values. The main disadvantage of this method is the significant labor costs required to perform measurements, since the duration of the repair can be up to 30 working days. However, a possible solution to this problem can be the introduction of geoinformation systems.

The geoinformation systems are widely used in the field of industrial safety. The systems include a set of high-tech components. The sensors can track the biometric indicators of employees and in case of their violations, determine the location of the person and provide the necessary medical assistance in a timely manner. However, we believe that they can be used in the analytical and research method for determining labor coefficient. The geoinformation system is a complex unit of two-way information exchange of the head unit and end sensors. The functionality of the sensors is designed to determine physical activity and determine the geo-position of workers. Having previously determined the standard scope of work, the head of the repair team or a representative of the operating organization notes the type of work performed step by step, recording the beginning and end of work for each type of repair work. The received data is accumulated in the database, and the operator decrypts it. Having accumulated a minimum sample of data on the labor coefficient of the repair, for the same type of equipment and the scope of work performed, it is possible to analyze and approve the final standard values for the scope of work, the qualification staff of the repair personnel, as well as labor consumption standards.

The calculation and analytical method is a more efficient way to determine labor coefficient and includes the following methods in the system for calculating labor costs [14]:

1) method of accounting for masses;

2) method of accounting the complexity of the equipment design;

3) method of multiple classification analysis;

4) microelement rationing of labor;

5) statistical method

The method of accounting for masses is based on a linear dependence on the mass (surface area) of processing equipment, which is an analogue, having similar design characteristics, processing parameters, a known value of labor coefficient and a coefficient that takes into account the geometric and weight characteristics of comparable equipment (Formula 4).

$$
\mathrm{T}=\mathrm{T}_{a n} \cdot \mathrm{K}_{w},
$$

Formula 4

$\mathrm{T}$ - labor coefficient of repair works;

$\mathrm{T}_{\mathrm{an}}$ - labor coefficient of analogue equipment repair;

$\mathrm{K}_{\mathrm{W}}$ - coefficient that takes into account the geometric and weight characteristics of comparable equipment.

Coefficient can be determined by the following method (Formula 5).

Formula 5

$$
\mathrm{K}_{\mathrm{w}}=\sqrt[3]{\left(\mathrm{M}_{\mathrm{eq}} / \mathrm{M}_{\mathrm{an}}\right)^{2}}=\mathrm{S}_{\mathrm{eq}} / \mathrm{S}_{\mathrm{an}},
$$

$\mathrm{M}_{\mathrm{eq}}, \mathrm{M}_{\mathrm{an}}$ - equipment mass, analogue equipment mass;

$\mathrm{S}_{\mathrm{eq}}, \mathrm{S}_{\mathrm{an}}$ - area of the proceeds surface, equipment, analogue equipment.

The method of taking into account the complexity of the equipment design is based on the use of the known value of the analogue equipment labor coefficient and the coefficient of complication of the processing features of the equipment. The value of the design features complication coefficient is determined by an expertise. The amount of labor coefficient using the method of taking into account the complexity of the design is determined (Formula 6). 


$$
\mathrm{T}=\mathrm{T}_{a n} \cdot \mathrm{K}_{d},
$$

$\mathrm{T}$ - labor coefficient of repair works;

$\mathrm{T}_{\mathrm{an}}$ - labor coefficient of analogue equipment repair;

$\mathrm{K}_{\mathrm{d}}$ - coefficient of complication of the technical features of the equipment.

The method of multiple classification analysis has become the most widespread and makes it possible to take into account the conditions for performing repair work. The labor coefficient of repair work is directly proportional to the basic indicator of labor coefficient and the coefficient characterizing the conditions for performing work (Formula 7).

Formula 7

$$
\mathrm{T}=\mathrm{T}_{\sigma} \cdot \mathrm{K}_{\text {con }},
$$

$\mathrm{T}$ - labor coefficient of repair works;

$\mathrm{T}_{\mathrm{b}}$ - basic indicator of labor coefficient under normal conditions;

$\mathrm{K}_{\text {con }}$ - coefficient that takes into account the conditions for performing repair work.

Microelement rationing also refers to the system of calculation and analytical methods, its peculiarity lies in the fact that any repair process can be decomposed into a number of such simple elements as "turn", "take", "put" and others.

Using this method will cover up to $80 \%$ of manual work. In addition, it becomes possible to study in detail the entire repair process performed by specialized departments. As a result, by changing the elementwise set of actions of a specialist performing repair work, it is possible to achieve more rational and efficient methods for performing repairs.

Statistical methods for determining labor coefficient are the most promising. Correlation and regression analysis is one of its varieties and determines the dependence of features on determining factors by building an economic and mathematical model in the form of a regression equation.

Correlation and regression analysis involves the following stages:

- preliminary analysis;

- collection and primary processing of information;

- building a model;

- evaluation and analysis of the model.

The use of calculating and analytical methods will speed up the development and increase the degree of provision of regulatory documents in the field of repair of processing equipment.

One of the ways to improve the repair business process at the scheduling stage is to increase the justification for the cost of repair work by updating and developing new regulatory documents.

\section{RESULTS}

For the effectiveness of arranging the repair production at the enterprises of the power generating sector, an assessment system that meets the following requirements is required:

- indicators should be available and display significant information for the main participants in the repair business process in terms of implementing their economic interests;

- assessment indicators should be unbiased and determine the effectiveness of the business process in stages and as a whole [15].

Abovementioned recommendations for determining the resulting indicators, according to the authors, can be used to determine the effectiveness of arranging the repair of processing equipment.

In order to determine the effectiveness of arranging the service maintenance at the enterprises of the power generating sector, it is proposed to introduce the following indicators:

- service maintenance performed in time (coefficient $\mathrm{K}_{\mathrm{t}}$ );

- completeness of the volumes of services provided in comparison with the planned (coefficient $\mathrm{K}_{\mathrm{V}}$ );

- he level of costs for service maintenance (coefficient $\mathrm{K}_{\mathrm{ex}}$ ); 
- availability of a ranking system necessary for determination the object of repair (coefficient $\mathrm{K}_{\mathrm{r}}$ );

- the degree of justification for the cost of repair work (coefficient $\mathrm{K}_{\mathrm{c}}$ ).

Evaluation of the effectiveness in arranging the maintenance service is performed as follows (Formula 8).

Formula 8

$$
\mathrm{K}_{\mathrm{ef}}=\mathrm{K}_{\mathrm{t}} * \mathrm{~K}_{\mathrm{v}} * \mathrm{~K}_{\mathrm{ex}} * \mathrm{~K}_{\mathrm{r}} * \mathrm{~K}_{\mathrm{c}} \text {, }
$$

$\mathrm{K}_{\mathrm{ef}}$ - criterion of the effectiveness in arranging the maintenance service.

Service maintenance performed in time is the compliance of the required (planned) and actual time of rendering services. This factor is assessed by the coefficient of the time of rendering services (Formula 9).

Formula 9

$$
K_{t}=\frac{B_{f}}{B_{p}}
$$

$\mathrm{K}_{\mathrm{t}}$-coefficient for assessing the timeliness of the services rendered;

$\mathrm{B}_{\mathrm{f}}-$ actual time of rendering services;

$\mathrm{B}_{\mathrm{p}}-$ required (planned) time of rendering services.

The completeness of the volume of services provided is estimated by the coefficient of the volume of services provided (Formula 10).

$$
\mathrm{K}_{\mathrm{v}}=\frac{\mathrm{O}_{\mathrm{f}}}{\mathrm{O}_{\mathrm{p}}}
$$

Formula 10

$\mathrm{K}_{\mathrm{V}}$ - coefficient of assessment of the volume of services provided;

$\mathrm{O}_{\mathrm{f}}$ - actual volume of services provided, units (units are indicated depending on the type of services provided);

$\mathrm{O}_{\mathrm{p}}$ - planned need for services, units (units are indicated depending on the type of services provided).

The ratio of planned and actual costs is estimated by the coefficient of maintenance service costs (Formula 11).

$$
\mathrm{K}_{\mathrm{ex}}=\frac{\mathrm{E}_{\mathrm{f}}}{\mathrm{E}_{\mathrm{p}}}
$$

Formula 11

$\mathrm{K}_{\mathrm{ex}}$ - maintenance service cost coefficient;

$\mathrm{E}_{\mathrm{f}}$ - maintenance service actual costs;

$\mathrm{E}_{\mathrm{p}}$ - maintenance service planned costs.

The presence of a ranking system when planning the repair works is characterized by the coefficient $\mathrm{K}_{\mathrm{r}}$.

If the enterprise uses a ranking system when determining repair objects $K_{r}=0.9$. When the enterprise does not have a ranking system $\mathrm{K}_{\mathrm{r}}=1.1$.

The degree of justification for the cost of repair work is determined using the coefficient $\mathrm{K}_{c}$, which characterizes the applicability of the current regulatory documents in determining the cost of repair work.

If the cost of repair work is determined using the standard values $\mathrm{K}_{\mathrm{c}}=0.9$.

In the case when the cost of repair work was determined by the actual labor costs $\mathrm{K}_{\mathrm{c}}=1.1$.

Table 3 "Scale of maintenance service performance levels"

\begin{tabular}{|c|c|l|}
\hline $\begin{array}{c}\text { Numerical } \\
\text { intervals } \mathrm{K}_{\mathrm{ef}}\end{array}$ & $\begin{array}{c}\text { Level of effectiveness of the service using } \\
\text { process in the organization }\end{array}$ & \multicolumn{1}{|c|}{ Possible actions in terms of the process } \\
\hline $\mathrm{K}_{\mathrm{ef}} \leq 1$ & High level & $\begin{array}{l}\text { The process is functioning effectively. No corrective } \\
\text { action required. }\end{array}$ \\
\hline $1<\mathrm{K}_{\mathrm{ef}} \leq 1,2$ & Medium level & $\begin{array}{l}\text { The process is functioning effectively, goals and } \\
\text { objectives are partially achieved, but corrective actions } \\
\text { need to be developed. }\end{array}$ \\
\hline $1,2<\mathrm{K}_{\mathrm{ef}} \leq 1,4$ & Low level & $\begin{array}{l}\text { The process is ineffective and significant corrective } \\
\text { actions need to be developed. }\end{array}$ \\
\hline $\mathrm{K}_{\mathrm{ef}}>1,4$ & Very low level & $\begin{array}{l}\text { The process is ineffective, requires management } \\
\text { intervention and the adoption of drastic management } \\
\text { decisions. }\end{array}$ \\
\hline
\end{tabular}

Source: compiled by the authors of the study. 
Based on the assessment performed, it is possible to develop measures to improve the efficiency of arranging own service or/and assess the possibility of transferring maintenance service functions to external organizations [16][17][18].

Table 4 "Varieties of management decisions based on the results of monitoring the values of performance parameters of the business process for the processing equipment repair"

\begin{tabular}{|c|c|c|}
\hline Criteria & Criteria value & Management decisions \\
\hline \multirow{3}{*}{ 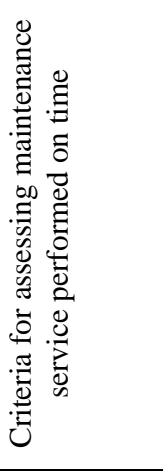 } & $\begin{array}{l}\text { Repair services provided } \\
\text { ahead of schedule }\end{array}$ & $\begin{array}{l}\text { Identifying the causes } \\
\text { Initiation of work on updating the documents regulating the labor coefficient and } \\
\text { the qualified level of personnel involved in the repair } \\
\text { Taking measures in order to optimize management processes for arranging repair } \\
\text { services }\end{array}$ \\
\hline & $\begin{array}{l}\text { Repair services were } \\
\text { provided on time }\end{array}$ & Not provided \\
\hline & $\begin{array}{l}\text { The deadline for the } \\
\text { repair work was higher } \\
\text { than the established }\end{array}$ & $\begin{array}{l}\text { Identifying the causes } \\
\text { Improvement of the system of the material stock formation } \\
\text { Initiation of work on updating the documents regulating the labor coefficient and } \\
\text { the qualified level of personnel involved in the repair } \\
\text { Initiation of the process of compensation by the guilty party } \\
\text { Improvement of the planning system for the arranging repair service }\end{array}$ \\
\hline \multirow{3}{*}{ 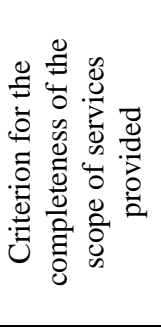 } & $\begin{array}{l}\text { The scope of services } \\
\text { provided was higher than } \\
\text { the customer's needs }\end{array}$ & $\begin{array}{l}\text { Identifying the causes } \\
\text { Improvement of the planning system for the arranging repair service }\end{array}$ \\
\hline & $\begin{array}{l}\text { The scope of services } \\
\text { provided met the needs } \\
\text { of the customer }\end{array}$ & Not provided \\
\hline & $\begin{array}{l}\text { The scope of services } \\
\text { provided was lower than } \\
\text { the customer's needs }\end{array}$ & $\begin{array}{l}\text { Identifying the causes } \\
\text { Improvement of the planning system for the arranging repair service Initiation of } \\
\text { the process of compensation by the guilty party }\end{array}$ \\
\hline \multirow{3}{*}{ 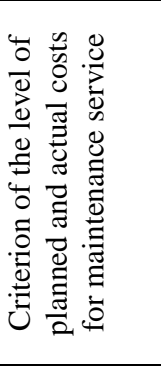 } & $\begin{array}{l}\text { The cost of the services } \\
\text { was higher than the } \\
\text { customer's needs and } \\
\text { there are cost savings }\end{array}$ & $\begin{array}{l}\text { Identifying the causes } \\
\text { Initiation of the process of compensation by the guilty party Improvement of the } \\
\text { system for the formation of material stock procurement } \\
\text { Improvement of the planning system for the arranging repair service }\end{array}$ \\
\hline & $\begin{array}{l}\text { The cost of the services } \\
\text { provided met the needs } \\
\text { of the customer }\end{array}$ & Not provided \\
\hline & $\begin{array}{l}\text { The cost of the services } \\
\text { provided was lower than } \\
\text { the customer's needs }\end{array}$ & $\begin{array}{l}\text { Identifying the causes } \\
\text { Improvement of the planning system for the arranging repair service }\end{array}$ \\
\hline \multirow[b]{2}{*}{ 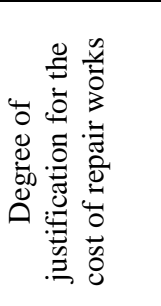 } & Justified & Not provided \\
\hline & Not justified & $\begin{array}{l}\text { Initiation of work on updating the documents regulating the labor coefficient and } \\
\text { the qualified level of personnel involved in the repair } \\
\text { Application of analytical and research as well as calculation and analytical methods } \\
\text { in order to determine the labor oefficient of repair work }\end{array}$ \\
\hline \multirow{2}{*}{ 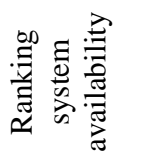 } & Available & Not provided \\
\hline & Not available & Initiate the development of a ranking system for processing units in operation \\
\hline
\end{tabular}

Source: compiled by the authors of the study.

The method for assessing the effectiveness of the maintenance service arrangement is used for a comprehensive assessment of the quality of the maintenance service arrangement. Using this method, it is also possible to identify problematic stages of the repair business process that require certain management decisions that can improve the quality of arranging repair services. 


\section{CONCLUSION}

Effective management of repair production in the gas industry implies information awareness of each repair facility, the achievement of the required quality indicators of the repair of processing equipment for further safe and cost-effective operation, and trouble-free operation of the enterprise. In this regard, it is necessary to introduce indicators characterizing the effectiveness of repair production.

It is also recommended to comprehensively use the analytical and research, as well as calculation and analytical methods for determining the labor coefficient during repair work presented in the paper. Since labor coefficient is a key criterion in determining the final cost of repairs, it is extremely important that the range of equipment used has approved standards of value. In the case of outsourcing, this will increase the justification of the cost of repair, and if there is an internal repair service, have its optimal number.

\section{ACKNOWLEDGEMENT}

This paper has been supported by the RUDN University Strategic Academic Leadership Program.

The article has been prepared within the framework of initiative research work No. 061607-0-000 entitled "A Comprehensive Solution for Improving the Economic Efficiency of the Coal Industry as a Condition for Strengthening Energy Safety of Russia", carried out on the basis of the National Economy Department, Faculty of Economics, RUDN University.

\section{REFERENCES}

[1] Brents A.D., Tishchenko V.G. Arrangement, planning and management of enterprises in the oil and gas industry. Moscow: Nedra. 1986. - 510 p.

[2] Chernyaev M.V., Pakhomov S.V. Innovative gas services. Russian and foreign experience // Economics and Entrepreneurship. - M.: BukiVedi. 2018. No. 10. - P. 786-789.

[3] MDS 13-14.2000 Provision on preventive maintenance of industrial buildings and structures. Approved by the Decree of the USSR State Construction Committee of December 29, 1973 No. 279.

[4] Scientific information platform for specialists in the field of industrial assets management of industrial enterprises URL - https://eam.su/1-sistema-texnicheskogo-obsluzhivaniya-i-remontovoborudo vaniya-2.html/ (date of access: September 29, 2017).

[5] Atamaniuk V.G., Lianzberg V.P., Kharchenko V.G. Ensuring reliable and safe operation of equipment // SOK (electronic journal). 2005. No. 8. URL - https://www.c-o-

k.ru/articles/obespechenie-nadezhnoy-i-bezopasnoy-ekspluatacii-oborudovaniya (date of access: April 29, 2016).

[6] Kudrevatykh A.V., Kuznetsov V.V., Khoreshok A.A. Characteristics of methods of maintenance of mining and transport equipment // Mining information and analytical bulletin. Moscow. 2011. No. 5. - P. 48-61.

[7] Arbuzov Y.A., Voevodin I.G., Grachev V.A., Dzioev S.K., Khimich V.N. Ranking of the sections of the linear part of the main gas pipelines for shutdown for repair // Gazovaya promyshlennost. 2010. No. 5. - P. 54-56.

[8] Afanasyev V.Y., Linnik Y.N. Oil and gas complex: production, economics, management. - Moscow: Economics, 2014. -717 p.

[9] Klyushnikova E.V., Shitova E.M. Methodological approaches to the calculation of the integral parameter, ranking methods // Electronic scientific and practical journal "Innocentre". 2016. No. 1. P. 4-18.

[10] Siutin D.A., Mitreikina I.V., Pakhomov S.V. Development of approaches to form the indicators of maintenance and repair of equipment in the oil and gas industry // Gas industry. 2018. No. 5. - P. $116-123$. 
[11] Siutin D.A., Mitreikina I.V., Pakhomov S.V. Research and assessment of factors affecting the value of labor coefficient of maintenance and repair of equipment in the oil and gas industry // Problems of Economics and Management of the Oil and Gas Complex. 2017. No. 6. - P. 25-31.

[12] Rudenko G.E. Labor results and their assessment // Standardizing and labor compensation in industry. 2015 No. 11-12. - P. 60-63.

[13] Mitreikina I.V., Pakhomov S.V., Siutin D.A. Improvement of approaches to the formation, justification and optimization of labor coefficient standards for repair work at the facilities of Gazprom PJSC // Gas industry personnel. 2017.No. 1 - P. 10-16.

[14] Chernyaev M.V., Pakhomov S.V., Methods for determining the reasonable level of labor coefficient of repair of processing equipment in the gas industry // Economic and humanitarian sciences. 2017. No. 11. - P. 112-119.

[15] Afanasyev A.V., Vaganov Y.V., Geykhman M.G., Dmitruk V.V., Kustyshev A.V. Unsolved problems of service repair of oil and gas wells in the fields of Western Siberia // Problems of Economics and Management of the Oil and Gas Complex. 2014. No. 10. - P. 15-18.

[16] Dixon J. Design Engineering: Inventiveness Analysis and Decision Макing. M.: Mir, 1969. - 440 p.

[17] Altschuler A.I., Kuznetsova Y.V. Features of the systems approach in the theory of arrangement // Kazanskaya nauka. 2010. No. 8. - P. 105-111.

[18] Ivanov A.Y., Plekhanova A.F., Yurlov F.F. The principles of selecting effective solutions in multilevel systems (on the example of the SC "Rosatom") // Economics and Entrepreneurship. 2015. No. 12-3. - P. 671-674.

\section{Article history:}

Received 10 April 2021

Accepted 12 July 2021 